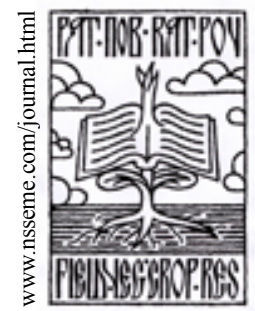

\title{
Some Characteristics of the Newly Obtained Constant Sweet Pepper (Capsicum annuum L.) Hybrids
}

\author{
Saida Sharifova • Sabir Hasanov • Alisoltan Babayev • Niyazi Guliyev
}

\author{
received: 22 November 2011. accepted: 25 January 2012. \\ (c) 2012 IFVC \\ doi: $10.5937 /$ ratpov $49-1212$
}

\begin{abstract}
Summary: A comparative study of the five constant hybrid forms of sweet pepper (Capsicum annuum L.) has been carried out. The hybrids have been chosen for their positive properties among different selection materials which turned out as a result of crossing of different sweet pepper varieties and hybrids mixed grown in the experimental field of Genetic Resources Institute in Azerbaijan. These hybrids differ from each other for the size, weight and taste of their fruits, productivity and other properties of plants. They were estimated as a valuable form for their agronomical important characteristics.
\end{abstract}

Key words: Capsicum, hybrids, pepper

\section{Introduction}

Pepper (Capsicum L.) is a member of the Solanaceae family and originates from South and Central America where American Indians domesticated it around 7,000 BC. Though Capsicum is a genus of about 30 species (Hunziker 2001), only five species were independently domesticated and have been cultivated primarily for use as a spice and vegetable for thousands of years (Andrews 1995).

Pepper is ranked third or fourth among vegetable crops worldwide, grown in most countries in the world with production acreages estimated at more than 7.5 million (The Chile Pepper Institute 2011). Peppers are also ranked first in antioxidant content among vegetables with very high levels of vitamin C. Carotenoid and anthocyanin pigments are responsible for fruit colour and for nutritional value of Capsicum fruits. Pepper fruits are a concentrated source of vitamins from the $\mathrm{A}, \mathrm{B}, \mathrm{C}, \mathrm{E}$, and $\mathrm{K}$ groups (Palevitch \& Craker 1995).

Most cultivated peppers are autogamous. In open field, out-crossing commonly ranges from $7 \%$ to $90 \%$ and this fact shows that Capsicum should be considered facultative cross-pollinating species (Odland \& Porter 1941, Franceschetti 1971).

S. Sharifova* $\bullet$ S. Hasanov • A. Babayev • N. Guliyev

National Academy of Sciences, Genetic Resources Institute, 155 Azadlig Ave., Baku, AZ 1106, Azerbaijan

e-mail: saidasharifzade@yahoo.com
Oppressing of local agricultural plants, especially vegetable varieties by the unknown hybrids has been observed recently. One of the principal causes of this problem is the depressing of quality parameters of the local pepper genotypes or loss of their former positive features in the result of pollination. On the other hand, numerous selection materials have arisen. Therefore, selection and breeding of high productive, new varieties is an important issue nowadays.

\section{Materials and Methods}

We have carried out the selection of agronomical important hybrids of sweet pepper through the individual selection among numerous mixed materials since 2007. The source materials have been taken from the gene bank of Genetic Resources Institute of ANAS, Azerbaijan. All of them had been obtained as the result of mixed planting of local and foreign genotypes for a long time.

Seeds have been treated with fungicides and pathogen-free seeds sown at the greenhouse condition. Seedlings have been transferred into the isolated open field when they were ready for transplanting. Seedlings of each genotype have been planted into row according to the $70 \times 30$ $\mathrm{cm}$ scheme at three repetitions. The agrotechnical practices such as irrigation, application of fertilizers, weed and etc. have been carried out at appropriate moments as well. 
The research has been carried out on the basis of the international plant descriptors (IPGRI 1995) and the variety testing methods of agricultural plants (Moscow 1978).

Different traits have been included in the research according to IPGRI descriptor for pepper (IPGRI 1995), namely stem colour (7.1.2.2), plant height (7.1.2.6), plant growth habit (7.1.2.7), branching habit (7.1.2.11), leaf density (7.1.2.13), leaf colour (7.1.2.14), leaf shape (7.1.2.15), days to flowering (7.2.1.1), number of flowers per axil (7.2.1.2), flower position (7.2.1.3), corolla colour (7.2.1.4), corolla shape (7.2.1.6), anther colour (7.2.1.8), days to fruiting (7.2.2.1), fruit colour at intermediate stage $(7.2 .2 .3)$, fruit colour at mature stage (7.2.2.6), fruit shape (7.2.2.7) fruit length (7.2.2.8), fruit width (7.2.2.9), fruit weight (7.2.2.10), fruit wall thickness (7.2.2.12), fruit shape at pedicel attachment (7.2.2.13), fruit shape at blossom end (7.2.2.15), number of locules (7.2.2.18), fruit surface (7.2.2.19) and 1000 -seed weight (7.3.5).

Table 1. Duration of vegetative period (days) Tabela 1 . Trajanje vegetativnog perioda (dani)

\section{Results}

The five constant hybrids of sweet pepper have been obtained through the mass selection among numerous mixed materials. Duration of vegetative periods and bio-morphological and economically valuable properties of constant sweet pepper (Capsicum annuum L.) hybrids №5, №9, №10, №11 and №12 has been studied comparatively with the standard variety Yadigar.

Yadigar is a local sweet pepper variety. Average height of plants is about $63 \mathrm{~cm}$ with intermediate branching habit. Flowers are in intermediate position at branch. Fruits are triangular and fruit shape at blossom end is pointed. Fruit colour is light green at intermediate stage and light red at mature stage. Fruit surface is smooth. Average weight of fruit is $80-90 \mathrm{~g}$.

The duration of vegetative period of hybrids has been illustrated in table 1 . As shown, the total length of vegetative period of all hybrid plants was 2-3 day shorter than standard variety. The period from mass germination to the technical ripening was one day longer in №5, same in №9 and one day shorter in all other hybrids in comparison with Yadigar.

Some characteristics of hybrid plants have been given below in table 2 .

\begin{tabular}{lcccc}
\hline Accessions & $\begin{array}{c}\text { From } \\
\text { germination until budding }\end{array}$ & $\begin{array}{c}\text { From germination until } \\
\text { flowering }\end{array}$ & $\begin{array}{c}\text { From germination until } \\
\text { technical ripening }\end{array}$ & $\begin{array}{c}\text { From germination until } \\
\text { biological ripening }\end{array}$ \\
\hline 1.Hybrid N0 5 & 63 & 82 & 106 & 139 \\
2.HybridNo9 & 64 & 82 & 105 & 137 \\
3.Hybrid№ 10 & 63 & 81 & 104 & 138 \\
4.Hybrid№ 11 & 63 & 82 & 104 & 138 \\
5.Hybrid№ 12 & 63 & 81 & 104 & 139 \\
6.Yadigar & 64 & 82 & 105 & 141 \\
\hline
\end{tabular}

Table 2. Some agriculturally important characteristics (average)

Tabela 2. Neke agronomski važne karakteristike (prosek)

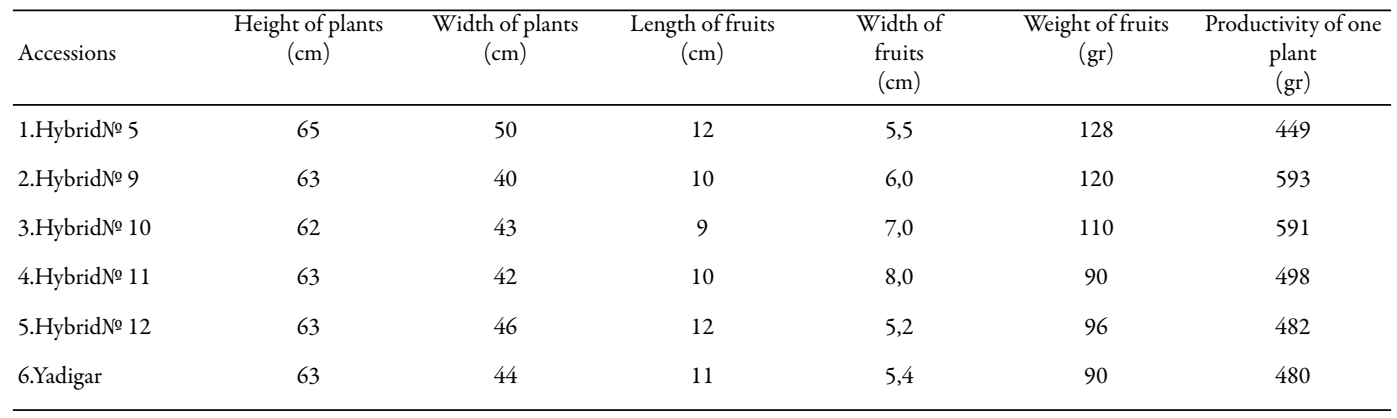


Hybrid №5. Average height of plants is about $65 \mathrm{~cm}$, fruits are triangular with 2-3 locules. Branching habit of plants and position of flower at branches is intermediate. Fruit shape at blossom end is pointed. Fruit colour is dark green at intermediate stage and dark red at mature stage. The thickness of flesh is 5-8 mm (Fig. 1).

Hybrid №9. Plants of hybrid №9 are characterized with intermediate branching habit and flower position. Fruit shape at blossom end is pointed. Fruits are triangular shaped, light green at intermediate stage and light red at mature stage. An average length of fruits is $10 \mathrm{~cm}$ and average weight is $120 \mathrm{~g}$. The thickness of flesh is 4-6 mm (Fig. 2).

Hybrid №10. Average height of plants is about $62 \mathrm{~cm}$ with intermediate branching. Flower position at branches is intermediate. Fruits shape is blocky with 4 locules and sunken and pointed at the end. Fruit colour is dark green at intermediate stage and dark red at mature stage. The thickness of flesh is $5-8 \mathrm{~mm}$ (Fig. 3.).

Hybrid №11. Plants are characterized with intermediate branching habit and triangular fruit shape. Flower position at branches is intermediate and fruit shape at blossom end is pointed. Number of locules in fruit is 3-4. Fruit colour is light green at intermediate stage and light red at mature stage. The thickness of fruit flesh is 4-6 mm (Fig. 4).

Hybrid №12. Average height of plants is about $63 \mathrm{~cm}$, branching habit is intermediate. Flower position is also intermediate. Fruits are triangular with 2-3 locules. Fruit colour is light green at intermediate stage and light red at mature stage. Fruit shape at blossom end is pointed. The thickness of fruit flesh is $5-8 \mathrm{~mm}$. The average length, width and weight of fruits are about $12 \mathrm{~cm}, 5.2 \mathrm{~cm}$ and $96 \mathrm{~g}$ respectively (Fig. 5).

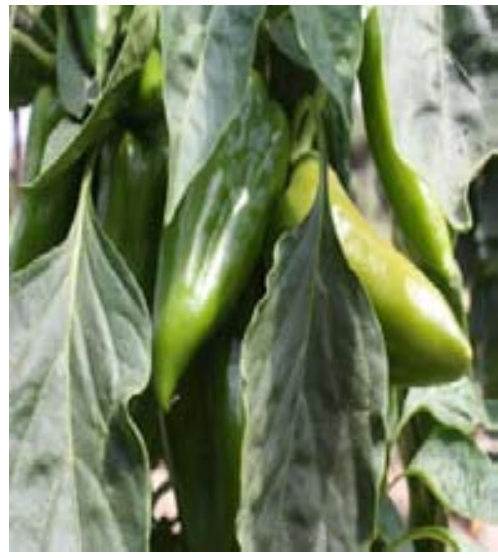

Fig. 1. Hybrid №5 Slika 1. Hibrid №5

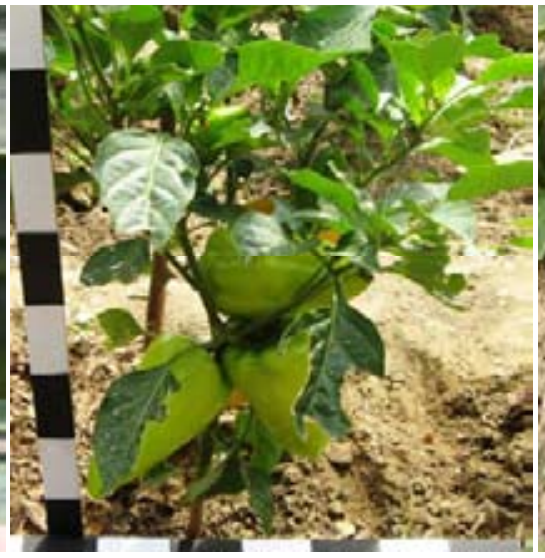

Fig. 2. Hybrid №9

Slika 2. Hibrid №9

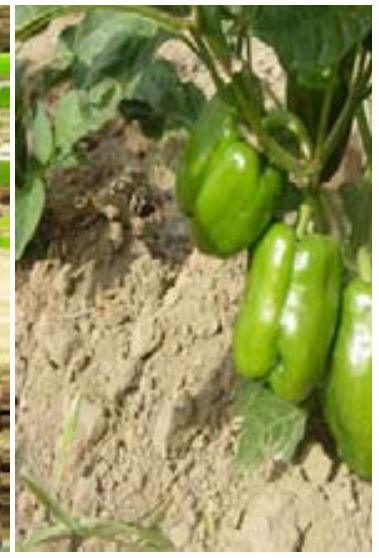

Fig.3. Hybrid №10

Slika 3. Hibrid №10

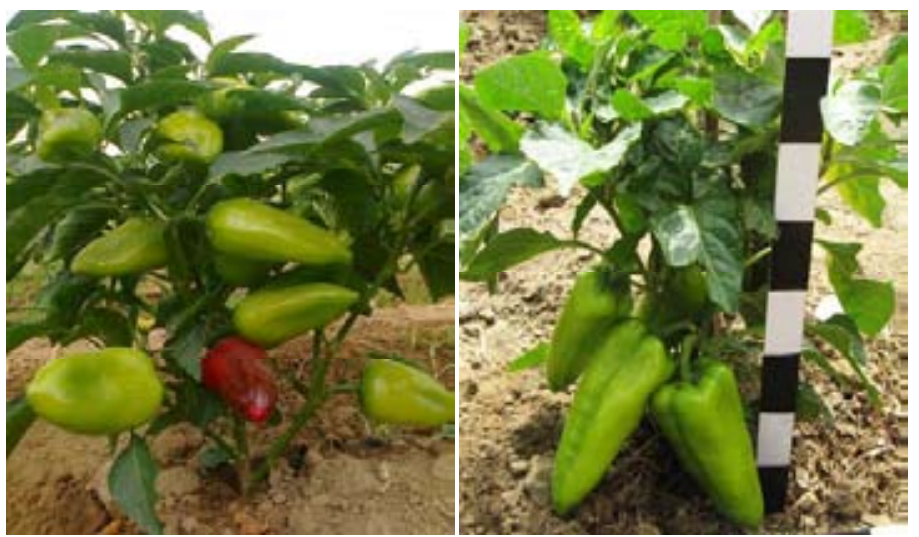

Fig. 4. Hybrid № 11 Slika 4. Hibrid №11
Fig.5. Hybrid №12

Slika 5. Hibrid №12 


\section{Conclusions}

It was defined that there was abundant selection material among the sweet pepper genotypes maintained at the gene bank of the Genetic Resources Institute in Azerbaijan. The principal cause of this genetic diversity was the open pollination among local genotypes, as well as among local and foreign genotypes imported into country from different neighbouring countries for a long time. The five constant hybrid forms have been obtained as a result of the selection among such different hybrids and varieties of sweet pepper taken from the gene bank. These hybrids are distinguished from each other regarding the size, weight and taste of their fruits and productivity of plants, and are estimated as a valuable form for their agronomically important characteristics. Further investigation on all of them has been continued.

\section{References}

Andrews J (1995): The domesticated Capsicums, new edition. University of Texas Press, Austin, TX, USA

Anon. (1978): Variety testing methods of agricultural plants. Moscow. 120 p.

IPGRI (1995): Descriptors for Capsicum (Capsicum spp.), IPGRI, AVRDC and CATIE. $110 \mathrm{p}$.

Franceschetti U (1971): Natural cross pollination in pepper (Capsicum annuum L.). Paper presented at Eucarpia Meeting on Genetic and Breeding of Capsicum, September 16-18, in Turin, Italy, 346-353

Hunziker AT (2001): Genera Solanacearum: The genera of Solanaceae illustrated, arranged according to a new system. ARG Grantner, Ruggell

Odland ML, Porter AM (1941): A study of natural crossing in peppers (Capsicum frutescens). Am. Soc. Hort. Sci. Proc. 38: 585-588

Palevitch D, Craker LE (1995): Nutritional and medical importance of red pepper (Capsicum spp.). J. Herbs. Spices. Med. Plants 3: 55-83

The Chile Pepper Institute (2011): Information. Available at www.chilepepperinstitute.org

\section{Neke karakteristike novih hibrida paprike (Capsicum annuum L.)}

\section{Saida Sharifova • Sabir Hasanov • Alisoltan Babayev • Niyazi Guliyev}

Izvod: Sprovedena je komparativna studija pet hibridnih formi paprike (Capsicum annuum L.) stvorenih u Institutu za genetičke resurse u Azerbejdžanu. Hibridi se razlikuju po veličini, težini, ukusu, produktivnosti i drugim agronomski važnim karakteristikama.

Ključne reči: Capsicum, hibridi, paprika 